\title{
LEAN MANUFACTURING IMPLANTATION IMPACTS: A STUDY ON A LARGE LOGISTICS OPERATOR
}

\section{IMPACTOS DA IMPLANTAÇÃO DO LEAN MANUFACTURING: UM ESTUDO EM UM OPERADOR LOGÍSTICO DE GRANDE PORTE}

\section{IMPACTOS DE LA IMPLEMENTACIÓN DEL LEAN MANUFACTURING: UN ESTUDIO SOBRE UN GRAN OPERADOR LOGÍSTICO}

Ester Eliane Jeunon

Doutorado em Psicologia pela Universidade de Brasília - UNB e Newcastle University - Austrália.

Professora da Fundação Pedro Leopoldo e professor adjunto IV da Pontifícia Universidade Católica de Minas Gerais - PUC Minas

esterjeunon@gmail.com

https://orcid.org/0000-0002-5158-0151

Francisco de Oliveira Júnior

MS em Administração, pela Fundação Pedro Leopoldo

fojunior82@yahoo.com.br

Leonora da Cunha Duarte

MS em Administração, pela Fundação Pedro Leopoldo.

leonoracduarte@gmail.com

Eloisa Helena Rodrigues Guimarães

Doutorado em Linguística pela Universidade Federal de Minas Gerais.Professora da Fundação Pedro Leopoldo.

eloisarodrigues@gmail.com

https://orcid.org/0000-0001-7050-0105

Editor Científico: José Edson Lara

Organização Comitê Científico

Double Blind Review pelo SEER/OJS

Recebido em 10.07.2020

Aprovado em 03.08.2020 


\begin{abstract}
Objective: This work aimed to analyze how the Lean methodology has caused changes in organizational processes in a logistics company.
\end{abstract}

Methodology: A descriptive and qualitative research was carried out in one of the branches of a large logistics operator located in the city of Vinhedo (SP). Questionnaires were applied and interviews were conducted with logistics experts, organization leaders, Lean Manufacturing managers and operators, coming to a total of 100 respondents, including organizational change factors such as Kaizen application for process improvement, 5S's for organization and cleaning and Kanban for production control.

Results: It was evident that factors such as productivity, quality, organization, among others were factors for the implantation of the methodology in the company.

Corporative results: The results revealed that after the implementation of Lean management, there were changes such as a better understanding of the proposed methodology, reorganization of processes and gain in productivity and quality, thus raising the level of competitiveness of the organization.

Keywords: Organizational change, Lean Manufacturing, Logistics.

\title{
Resumo
}

Objetivo: Este trabalho objetivou analisar de que forma a metodologia Lean impactou mudanças nos processos organizacionais em uma empresa de logística.

Metodologia: Foi realizada uma pesquisa descritiva e qualitativa em uma das filiais de um operador logístico de grande porte localizado na cidade de Vinhedo (SP). Foram aplicados questionários e realizadas entrevistas com especialistas em logística, líderes da organização, a gestora de Lean Manufacturing e operadores, sendo um total de 100 respondentes, onde foi possível identificar fatores de mudança organizacional como, aplicação de Kaizen para melhoria de processos, 5S's para organização e limpeza e Kanban para controle de produção.

Resultados: Ficou evidente que fatores como produtividade, qualidade, organização, dentre outros foram fatores para implantação da metodologia na empresa.

Contribuições corporativas: Os resultados revelaram que pós implantação da gestão Lean, houve mudanças como o melhor entendimento da metodologia proposta, reorganização de processos e ganho de produtividade e qualidade, elevando assim, o nível de competitividade da organização.

Palavras-chave: Mudança Organizacional, Lean Manufacturing, Logística.

\section{Resumen}

Objetivo: Este estudio tuvo como objetivo analizar cómo la metodología Lean impactó los cambios en los procesos organizacionales en una empresa de logística. 
Metodología: Se realizó una investigación descriptiva y cualitativa en una de las sucursales de un gran operador logístico ubicado en la ciudad de Vinhedo (SP). Se aplicaron cuestionarios y se realizaron entrevistas con especialistas en logística, líderes de organización, gerentes y operadores de Lean Manufacturing, con un total de 100 encuestados, donde fue posible identificar factores de cambio organizativos como la aplicación Kaizen para la mejora de procesos, 5S's para Organización y limpieza y Kanban para control de producción.

Resultados: Se quedó claro que factores como la productividad, la calidad, la organización, entre otros, fueron factores para la implementación de la metodología en la empresa.

Contribuiciones corporativas: Los resultados revelaron que después de la implementación de la gestión Lean, hubo cambios, como una mejor comprensión de la metodología propuesta, la reorganización del proceso y la productividad y la ganancia de calidad, lo que aumentó el nivel de competitividad de la organización.

Palabras clave: Cambio organizacional, Lean Manufacturing, Logística.

\section{Introduction}

In the current scenario of constant change, companies must constantly adapt to maintain a competitive pace. In this context, factors such as quality, cost and timeframe play a fundamental role in the success of organizations (Bakari, Rahim Yusof \& Ahmad, 2012). A significant part of the publications on the organizational change required to maintain this competitiveness describe ways in which companies adapt to meet new consumer demands, to the largest number of companies in the market, shorten the product life cycle, change the demands of consumers, alter workforce treatment demands, among other factors (Santos, 2014).

Effective management of logistics activities, the focus of the study reported here, can be a lever for the competitiveness of a company. Therefore, for proper management of logistics processes such as transportation storage (internal or external), handling and management of materials, information, internal communication and customer service, waste disposal is required. providing continuous improvement to its performance (Wu, 2003).

The Lean philosophy promotes in its methodology the constant and systematic elimination of losses, either in non-value-added process steps or even in activities that are related to any value-added production process (Barreto, 2012). Through principles and tool sets, the focus is on achieving waste disposal, process optimization, the elimination of non-valueadded activities, and the involvement of human resources in continuous improvement. However, the use of methods and tools is not in itself an advantage for the organization, it is 
necessary to involve the people of the organization (Dombrowski \& Mielke, 2013). Transportation companies also benefit from lean manufacturing principles and tools. Typically, this application is called Lean Production or Lean Manufacturing (Jones, Hines \& Richa, 1997).

Thus, this text aims to report how the implementation of the Lean methodology impacted changes in the organizational processes of a logistics company in the city of Vinhedo (SP). To this end, the organizational change process promoted by the implementation of the methodology in the company will be characterized, the main assumptions of the methodology applied to logistics will be identified, as well as the aspects that motivated its implementation in the organization and the way it was planned and implemented. Finally, the most relevant results obtained until the moment of the research will be reported.

This text is composed by this introduction that presents aspects about the need for organizational change due to competitiveness and the importance of Lean methodology to reach this objective, contextualized for logistic activities, focus of this study. Following, the concepts that underlie the research are approached, such as organizational change, Lean methodology and the fundamental concepts of logistics. Then, the methodology used for the research is characterized and its results are presented and analyzed. Finally, the final considerations of the study are presented.

\section{Literature Review}

In this section, the theoretical framework of the work is presented through the approach of the themes: organizational change; Lean methodology and logistics concepts.

\subsection{Organizational change}

Organizational change includes changes primarily in human behavior, as well as work regulations and corporate values in response to strategic changes (Herzog, 1991). The fundamental steps that constitute a change model must comprehend each variable in the organization system, determining their degree adjustment proportion, leading the organization to move to the desired direction (Melo, Macedo \& Medeiros, 2008).

Mildeberger (2011) asserts, however, that profound changes that imply strategy reorientation tend to be delayed by companies. For the author, organizations can cope well with 
incremental changes, but they do not see the need for a reorientation to a more radical organizational change.

Distinguishing between progressive and strategic change in the different possible dimensions is important for the successful implementation of organizational change. Whether strategic, cultural, technological, human, structural or political change, organizational change must be understood as well as the reasons that drove the process and the possible consequences on people's behavior (Pinto \& Lyra, 2009).

Regarding resistance to organizational changes, Abreu (2014) mentions that it can be defined as a force that contributes to stability in personality or social systems. Moreover, resistance in organization can be interpreted as a simple inertia of human nature, when the cause of non-change in individuals may be due to forces that hinder innovation. Change should not be considered a tool of change for factors of production or physical capital, but for people. After all, regardless of the subjectivity that the subject may appear to adapt to changes and pressures, it becomes difficult for him to change his worldviews.

\subsection{Lean methodology}

In the midst of destruction, and under American intervention, Japan, after the end of World War II, underwent political and economic reform, with the great challenge of regaining sovereignty and wounded pride. In this context, there have been several initiatives to improve efficiency and quality. Eiji Toyoda and Taiichi Ohno, the former, one of Toyota Motors' founding family executives, and the latter, the company's chief engineer, took bold ideas after a visit to Ford in the United States in 1950. Both reinvented Toyota's production process, calling it the Toyota Production System. This revolutionary system conquered the world in the 1970s through the results obtained through efficient management (Correa, 2007).

The Toyota Model spreads its idea as a culture, which has principles that, as highlighted by Liker e Hoseus (2009), configure the 4P Model, whose acronym comes from the English expressions: Philosophy, Process, People and Partners and Problem Solving. According to Neves (2011), the structure of the Toyota Production System (TPS) has changed and been improved for decades, nowadays reaching the structure that is easily identified by the pillars of the methodology, which, combined, allow any company achieve excellence in quality, low cost and shorter lead time. 
For Liker and Hoseus (2009), the Toyota management system is a long-term philosophy described by 14 principles: 1) base management decisions on a long-term philosophy, even to the detriment of short-term financial goals; (2) create a continuous process flow to bring issues up; (3) use pull systems to prevent overproduction; (4) leveling the workload (heijunka) working like the tortoise, not the hare; (5) build a culture of stopping and solving problems, achieving quality on the first try; (6) standardized tasks are the basis for continuous improvement and employee empowerment; (7) use visual control so that no problems are hidden; (8) use only reliable and fully tested technology that meets employees and processes; (9) develop leaders who fully understand work, who live philosophy and teach it to others; (10) develop exceptional people and teams that follow the company's philosophy; (11) respect their network of partners and suppliers by challenging them and helping them to improve; (12) see for yourself to fully understand the situation (GenchiGenbutsu); (13) make decisions slowly for consensus, fully considering all options; implement them quickly; 14) become a learning organization through tireless reflection (hansei) and continuous improvement (kaizen).

Lean Manufacturing or Lean Production is guided by the foundations of TPS and has emerged as a production system that focuses on streamlining processes and procedures from continuous waste reduction, such as excess stock between workstations and long waiting time (Riani, 2006).

Lean Thinking, that is, lean thinking to make Lean happen, is a management philosophy for creating value for the business by eliminating waste in any organization (Womack, Jones and Ross, 2004). Key objectives are focused on: streamlining processes to increase productivity, reduce costs and rework operational and organizational processes.

Among the various means for applying the Lean philosophy or methodology, it is possible to identify the main tools and their characteristics:

- Six sigma: aims to continually improve and reduce process variability with a customer-focused, fact-based approach and the use of quality tools to identify and minimize the causes and effects of problems; aims for activities to generate a maximum of three or four defects per million opportunities; The implementation methodology is DMAIC, which means define, measure, analyze, improve and control (Rasis, 2003).

- Muda, mura, muri: mean adverse causes in a process, which are addressed by the Lean methodology, and can be divided into two categories: 1) activities that do not add value to the customer and cannot be eliminated;2) activities that do not generate 
value perceived by the consumer, but that can be eliminated immediately (Womack et al., 2004).

- Kanban: production control tool, using card techniques that determine the manufacture of the batch of parts in a given work center (Shingo, 1991).

- Kaizen: preaches continuous and progressive improvement of activities to create more value while reducing waste; can be expanded to all areas of an organization, promoting improvements and streamlining processes (Womack et al., 2004).

- Poka-yoke: enables quality at source, with the aim of addressing the causes of errors that cause defects and manufacturing or operation failures; aims to improve machine safety systems (Shingo, 1991).

- Jidoka: gives employees autonomy so that they do not propagate problems arising from previous operations or even from suppliers that may interrupt production; ensures that nonconformities pass in processes ahead, but their causes can be preemptively addressed by the operators themselves (Kach, Oliveira, Veiga \& Galhardi, 2014).

- Just in time: it is based on the planned elimination of all waste and continuous improvement in productivity (Liker \& Hoseus, 2009).

- 5 S: systematic planning of classification, order and cleanliness, in order to ensure productivity, safety, organizational climate and motivation (Osada, 1992).

Implementing a project based on the Lean methodology requires a project management approach that involves people, planning and execution so that existing risks are always mitigated. Therefore, the proposal must be planned and implemented by an engaged team, with leaders capable of mobilizing resources and teams for the absorption and dissemination of projects (Liker \& Hoseus, 2009).

\subsection{Logistics: main concepts and aspects}

Today, globalization and the use of the internet have given logistics a considerable evolution. People needs have also changed because, when by purchasing products from the comfort of their own homes, logistics has become crucial in complementing consumer satisfaction. 
In his logistics conceptualization, Ballou (2010) considers that integrated logistics management is empowered to rationalize operating costs, improve service and transform the environment, promoting the rise of logistics as a whole and becoming a strategy of the organizations. Business logistics assesses how management can provide better levels of service and profitability to customers by planning, controlling and organizing warehousing and handling activities to facilitate the flow of product distribution.

Bowersox and Closs (2010) emphasize that material movement is not only limited to moving, boxing and storing, but also performing these functions, taking into account the time and space available. Production support activities should not be viewed as an isolated and independent number of procedures, they should be integrated into a system of activities in order to maximize the total productivity of a facility or warehouse.

\section{Methodology}

This research reported here is characterized as descriptive of qualitative nature, presenting itself as a case study, conducted through field research and documentary research. With this method, it was possible to describe the characteristics of a logistics segment organization, before and after implementing Lean Manufacturing to demonstrate the process of organizational change.

The study analysis unit was a company located in the city of Vinhedo (SP) that employs about 550 employees. The observation unit consisted of logistics experts, organization leaders, Lean Manufacturing manager and operators, totaling 100 respondents.

Regarding data collection, it has begun with document analysis on internal documents made available by the company. Then, two types of survey questionnaires were applied (Table 1), both Likert type. The first questionnaire was applied at the beginning of the implementation of the Lean methodology to 100 managers and leaders of the organization. The second was applied after the implementation and was also directed to 100 managers and leaders - among them there were respondents who participated in the initial survey and others who participated in the Lean introduction process.

Still regarding data collection, in order to obtain more detailed information about the impact of Lean implementation in the organization, semi-structured interviews were also conducted with the company's director of operations, the manager responsible for logistics planning and the Lean manager of the company, who has extensive knowledge on the subject. 
The interview questions were about the implementation process, the tools used and the impacts on the organization.

\section{Table 1}

Survey quizzes

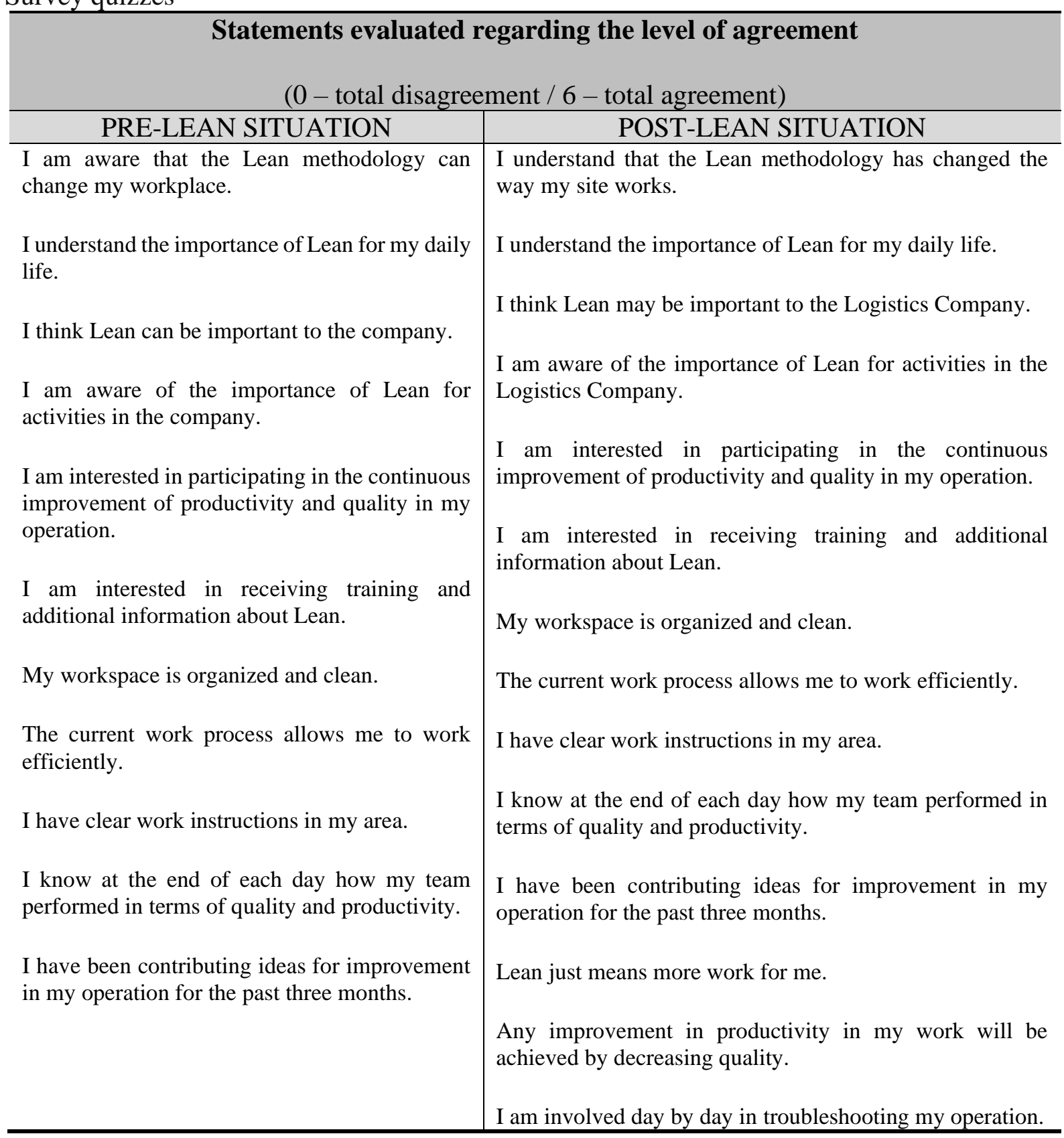

Source: research data (2017). 
The evaluation of the results obtained after data collection occurred through the interpretation of the level of agreement shown in the questionnaires (applied before and after the implementation of the methodology) and the discourse analysis of the interviewees during the semi-structured interviews.

\section{Results and Analysis}

This section presents the results and its analysis. It is comprised of the characterization of the company and respondents, assessment of the company's situation prior to the deployment of Lean (based on documented information surveyed and initial questionnaires), and subsequently results obtained after the implementation of Lean (based on the analysis of complementary questionnaires and interviews).

\subsection{Company and respondents' characterization}

At the request of the management of the organization, it will not be identified. However, despite the request for confidentiality, all information necessary to conduct the study was granted, including openness to the application of questionnaires and interviews.

From the documentary research conducted, it was possible to verify that the company is recognized in the corporate environment, especially for its ability to handle all the details of specific logistics needs. The company has a very diverse team of people in every part of the world. In all there are over 41,000 employees around the world, with highly committed and talented people. For this, the company relies on supply chain professionals, business leaders, experts in logistics, sales, finance, purchasing, human resources, and information technology. The organizational structure of the company under study has a horizontal model that includes several operations support departments. Its structure is divided into business units, which are cost centers.

As already mentioned in this report, the research was conducted at the unit located in the city of Vinhedo (SP), where the company operates in the storage and distribution of products throughout the national territory. About the participants of the questionnaires and interviews, the following are the main characteristics verified: 
- Regarding education, 70 respondents have high school, 18 have higher education and 12 have postgraduate education. This represents that there is a considerable slice of people who are sufficiently trained to understand the issues inherent in the process of change proposed by Lean.

- Among the interviewees, 49 have been working at the company between 3 and 7 years, 20 have been working there over 7 years and 31 have been there only for 3 years. There were no respondents who have been there less than 6 months. Such profile corroborates the possibility of valid answers from such respondents regarding the research of the situation before and after the implementation of Lean.

\subsection{Situation before Lean implementation}

After undergoing a broad process of reorganization in the organizational management structure, the company began to disseminate the culture of continuous improvement internally. The first step, still incipient, for the implementation of Lean Thinking, was the collection of suggestions by the collaborators of the areas, which aimed to record the existing problems under operational and human aspects. From then on, a specific sector was created in the company, called Lean, in which not only the suggestions, but the whole process of change, posture and operational conduct began to be managed. At the time of the establishment of the Lean sector, the internal research described in this report was performed as the initial questionnaire, consisting of statements for which respondents should evaluate the personal level of agreement. As main results, it is possible to highlight:

- For the respondents, the understanding of the results of the changes that the Lean methodology could bring about was inexpressive, since the vast majority disagreed with this statement.

- Regarding the understanding of the importance of Lean for their daily lives, the vast majority $(82 \%)$ disagreed with the statement, which corroborates the observation of the lack of theoretical knowledge about Lean at the beginning of its application.

- Regarding the importance of Lean for the organization, the answers were more divided regarding agreement or disagreement, being possible to say that the respondents had the notion that the methodology would be much more valid for the organization and less for themselves. 
- The other aspects of the questionnaire followed the same line that the methodology would be important (for the organization), but difficult for them. One highlight was that even early in the deployment, respondents massively agreed that they were receiving the necessary information about Lean.

Overall, the results obtained at the time of Lean implementation certainly allowed Lean managers and precursors in the organization to glimpse immediate opportunities that could contribute to positive short-term results.

\subsection{Situation after Lean implementation}

With the Lean methodology in place and its principles being adopted in the organization, the respondents participated in a questionnaire similar to the initial one, in which the statements were changed to evaluate the processes already underway, to which some additional statements were added (as can be seen in Table 1). The following are the most significant results observed:

- Regarding the consciousness about the impact of Lean methodology on the workspace, $92 \%$ of respondents partially or fully agreed. This demonstrates that the implementation of Lean concepts and their dissemination created certain conviction among the collaborators, so that there is little doubt about this issue.

- In statements about the importance of methodology for personal aspects, changes of opinion were the most significant in relation to the results before its implementation, since $94 \%$ of respondents came to partially or fully agree with the philosophy.

- According to the answers of the second questionnaire, Lean became important not only from a conceptual point of view, but also for logistics service activities.

- The use of Lean in the company, according to the respondents, promotes organizational changes, but also personal, because its teachings provide openings for those who excel in positivist attitudes, that is, that provide a performance worthy of Lean philosophy, with creation of values, waste reduction, increased productivity and organization. Thus, when asked if there is interest in participating in the continuous improvement of productivity and quality, the agreement was almost unanimous, with $98 \%$ of favorable answers.

- Regarding the understanding of the work environment after the implementation of Lean, unlike the initial interview, the answers were very positive, as $98 \%$ of 
respondents agreed that the environment was partially or fully adequate. This is the confirmation that the Lean philosophy has caused considerable organizational changes in the day to day life of the company and its employees.

Based on the results of the research, conducted as a master's dissertation and now briefly reported, it is possible to state that the dissemination of Lean culture in the company was based on the dissemination of philosophy's thinking and the persuasion of employees. During the research, it was also possible to notice that the concepts are applied daily, according to previous answers and later demonstrations of Lean practice in the company.

About the process of implementation of the methodology itself, through interviews with the director, the logistics manager and the Lean manager of the organization, it was possible to verify through the discourse analysis that: Lean is currently a methodology and a sector active in the company; helps define what standardized jobs are, the work instructions that will be required for that operation, and which KPIs (key performance indicators) should be tracked; operators, assistants and lecturers are already trained with the Lean vision; the company has adopted the site classification assessment (its own excellence assessment tool, which serves as a parameter to help the various sites - subsidiaries - that the company has in Brazil and worldwide); several Lean tools are used, among which are kaizen, 5S, just in time and kanban.

The application of Lean in the company was justified throughout the research for its ability to improve or optimize company productivity. This was verified through various indicators related to increased productivity, reduction in the level of complaints, among others presented by the organization during the documentary research and interview.

\section{Final Considerations}

Given the objective of analyzing how the Lean methodology impacted changes in organizational processes in a logistics company, the development of the research allowed the perception that the company studied treated the use of Lean methodology as a form of rule, objective and culture. For these reasons, it is already clear that the change was a fact, mainly because the application of the verb "change" in the company was treated very seriously, not only in Brazil, but in all its branches around the world.

The pre-Lean condition showed that the implementation of this behavioral change in the company would not be easy in its beginning, due to the resistance from the employees who did not know this methodology. In the post-Lean condition, the evaluation showed considerable 
improvement in the confidence level of employees directly linked to the production process, with a level of acceptance considered very good, even due to the continuity of the methodological practice.

Even with the variety of services the company provides within the supply chain, even with varying customer needs, and even with different product management, these issues have not become a stumbling block for the company to adopt Lean's core tools. kaizen, the 5S, just in time and kanban. All the tools were applied at different times and, at the same time, it can be said, since at the beginning of the change process the main tool used was the kaizen. It is also a fact that, even though, in the interviews, the participants did not mention the other tools (such as poka-yoke and jidoka), in a participant observation made, such occurrences were verified.

As a proposal for future studies, we can develop a research that quantifies the economic return that the company had or has had using the Lean methodology, complementing this study in order to corroborate the statement made by managers when they mentioned the economic impacts on the company. In terms of limitation, the survey did not find information from other branches of the company, due to the non-authorization of the company and other customers.

\section{References}

Abreu, M. S. A. (2014). Os desafios do processo de mudança organizacional numa empresa familiar: um estudo de caso. (Dissertação de Mestrado em Administração. Centro Universitário UNA, Belo Horizonte, MG, Brasil). Recuperado de: https://tinyurl.com/ya9brpm7

Bakari, A. H., Rahim, A. R. A., Yusof, N. M., \& Ahmad, R. (2012). Boosting LEAN Production via TPM. Procedia - Social and Behavioral Sciences, 65(3), 485-491.

Ballou, R. H. (2010). Gerenciamento da cadeia de suprimentos, logística empresarial. Porto Alegre: Bookman.

Barreto, A. R. (2012). Sistema Toyota de produção: Lean Manufacturing aplicação de princípios básicos em uma indústria de peças automotivas. Tékhne $\varepsilon$ Lógos, 3(2), 1-15.

Bowersox, D. J., \& Closs, D. J. (2010). Logística empresarial, o processo de integração da cadeia de suprimentos. São Paulo: Atlas.

Correa, C. (2007). Por dentro da maior montadora do mundo. Revista Exame, 892, 22-30.

Dombrowski, U., \& Mielke, T. (2013). Lean leadership: fundamental principles and their application. Procedia CIRP, 7, 569-574.

Herzog, J. P. (1991). People: the critical factor in managing change. Journal of Systems Management, 42(3), 6-11.

Jones, D., Hines, P., \& Rich, N. (1997). Lean Logistics. International Journal of Physical Distribution \& Logistics Management, 27(3), 153-173.

Kach, S. C., Oliveira, R., Veiga, L. R., \& Galhardi, A. C. (2014). Implementação do método kanban em célula de montagem dos componentes plásticos para linha de implementos 
agrícolas. Anais do $11^{o}$ Simpósio de excelência em gestão e tecnologia. Resende, Rio de Janeiro, RJ, Brasil.

Liker, J. K., \& Hoseus, M. (2009). A cultura Toyota: a alma do modelo Toyota. Porto Alegre: Bookman.

Melo, R. M. M., Macedo, R. S., \& Medeiros, D, D, (2008). A adoção da gestão de mudanças para a implementação da melhoria contínua da qualidade. Anais do $28^{\circ}$ Encontro Nacional de Engenharia de Produção. Rio de Janeiro, RJ, Brasil.

Mildeberger, D. (2011). A evolução da área de recursos humanos frente ao ambiente de mudanças organizacionais. Recuperado de: https://tinyurl.com/kuwckbh

Neves, A. A. (2011). Logística enxuta aplicada a um centro de distribuição. (Dissertação de Mestrado em Administração. Universidade de São Paulo, São Paulo, SP, Brasil). Recuperado de: https://tinyurl.com/y82duazu

Osada, T. (1992). Housekeeping, 5S: seiri, seiton, seiketsu, shitsuke. São Paulo: Instituto IMAN.

Pinto, M. C. S., \& Lyra, C. C. (2009). Mudança organizacional em uma empresa familiar brasileira. Revista de Administração Pública, 43(3), 609-634.

Rasis, D. (2003). Paper organizers international: a fictitious Six Sigma green belt case study. Quality Engineering, 15(1), 127-135.

Riani, A. M. (2006). Estudo de caso: o Lean Manufacturing aplicado na Becton Dickinson. (Tese de Doutorado em Engenharia de Produção, Universidade Federal de Juiz de Fora, Juiz de Fora, MG, Brasil). Recuperado de https://tinyurl.com/ybgjvzfy

Santos, M. S. S. (2014). Gestão da mudança organizacional: uma revisão teórica. (Dissertação de Mestrado em Administração. Fundação Getúlio, Rio de Janeiro, RJ, Brasil). Recuperado de: https://tinyurl.com/y86fsbqh

Shingo, S. (1991). Study of Toyota production system from industrial engineering viewpoint. Tokyo: Japan Management Association.

Womack, P. J., Jones, D. T., \& Roos, D. (2004). A máquina que mudou o mundo. Rio de Janeiro: Elsevier.

Wu, Y. C. (2003). Lean Manufacturing: a perspective of Lean suppliers. International Journal of Operations \& Production Management, 23(11), 1349-1376. 